Łukasz Ryszka

(D) https://orcid.org/oooo-0ooI-8267-7426

Uniwersytet Papieski Jana Pawła II w Krakowie

\title{
Pedagogiczne interpretacje mitów współczesnej edukacji człowieka
}

(60) https://doi.org/10.15633/9788374389839.15

Przemiany, jakie dokonują się obecnie we współczesnym świecie, są najlepiej widoczne w obszarach rozwoju i postępu technicznego. Zasięg ich oddziaływania jest podobny do zmian, jakie dokonały się w wyniku rewolucji przemysłowej w XVIII i Xıx wieku. Dotykają one nie tylko gospodarki państw i ich wymiaru ekonomicznego, ale prowadzą do zmian niemal we wszystkich innych dziedzinach życia społecznego. Przede wszystkim w Xx wieku, zwłaszcza w jego drugiej połowie, nastąpił intensywny rozwój naukowo-techniczny, który poprzez nieustanne doskonalenie istniejących już konstrukcji oraz wymyślanie coraz to nowszych produktów i technologii decyduje obecnie o sile rozwoju danego państwa, jego gospodarki i społeczeństwa ${ }^{1}$.

Szczególnie istotny jest rozwój informatyki, dla której przełomowym rokiem był 1981, ponieważ wówczas wprowadzono do sprzedaży tzw. PC, czyli komputer osobisty. Spowodowało to, że cyfryzacja wkroczyła do większości dziedzin życia. Rozwój nauki oraz kolejne techniczne nowości dzięki temu znacznie przyśpieszyły. Nowym określeniem wzbudzającym dziś społeczną ekscytację jest „technika burząca status quo”, które oznacza innowacje zastępujące istniejącą technikę w natychmiastowy i rewolucyjny sposób, np. kamery w smartfonach zastępujące tradycyjną fotografię albo strumieniowanie muzyki zastępujące płyty $\mathrm{CD}^{2}$.

1 Por.Z. Tyszka, Rodzinawświecie wspótczesnym - jej znaczenie dla jednostki ispołeczeństwa, w: Pedagogika społeczna. Człowiek w zmieniającym się świecie, red. T. Pilch, I. Lepalczyk, Warszawa 1995, s. 141.

2 Por. E.U. von Weizseacker, A. Wijkman, Kapitalizm, krótkowzroczność, populacja iznisz- 
Współczesne pokolenie określane jest popularnie jako „cyfrowi tubylcy”3, czyli osoby, które nie znają świata bez komputerów i aktywnie korzystają z wszelkiego rodzaju mediów i technologii cyfrowych. Zachowanie „cyfrowych tubylców” zmienia się - w gwałtowny sposób - równolegle z cyfryzacją całego społeczeństwa. Zazwyczaj cieszą się oni z zaburzenia status quo, które one powodują. Jednak istnieją także w społeczeństwie „cyfrowi imigranci”, czyli osoby, które dorastały jeszcze w świecie technologii analogowych wśród książek, długopisów i papieru. Wprawdzie osoby te weszły i poznały technologie cyfrowe, a nawet fascynują się nimi, jednak jest to jeszcze pokolenie, dla którego bezpośrednie relacje społeczne są istotną normą ich kontaktów.

We współczesnej charakterystyce społecznej zasadniczą rolę odgrywa więc przepływ informacji, który spotęgował się wielokrotnie w skali poszczególnych społeczeństw oraz w skali całego świata. Społeczeństwo oparte na wiedzy nastawione jest w obszarze działań na gromadzenie danych oraz informacji, ich przetwarzanie oraz dystrybucję. W sytuacji nadmiaru informacji powstaje „smog informacyjny”. Dlatego, jak pisze T. Hejnicka-Bezwińska, pedagogicznym wyzwaniem dla praktyki edukacyjnej jest przygotowanie ludzi do życia w świecie nadmiaru dostępnej każdemu wiedzy ${ }^{4}$.

Jean Maritain podkreślał, że istnieją dwa podstawowe cele wychowania: kształtowanie dojrzałego człowieczeństwa oraz uzdolnienie wychowanka do udziału w życiu społecznym. Zatem najważniejszym celem wychowania jest ukształtowanie dojrzałej osobowości człowieka oraz jego aktywnej postawy wobec życia ${ }^{5}$.

Ważnym czynnikiem staje się więc socjalizacja, poprzez którą osoba nabywa system wartości, norm oraz istotne wzorce zachowań, obowiązujące w danej społeczności. Skutkiem braku właściwej socjalizacji jest najczęściej egoizm, który nie tylko utrudnia kontakty międzyludzkie w życiu dorosłym, lecz również prowadzi do postaw konsumpcyj-

czenie planety. Raport Klubu Rzymskiego, Sztokholm 2018, s. 71.

3 Por. M.R. Jabłońska, Człowiek w cyberprzestrzeni. Wprowadzenie do psychologii internetu, Łódź 2018, s. 14.

4 Por. T. Hejnicka-Bezwińska, Pedagogika ogólna, Warszawa 20o8, s. 178; P. Legutko, Szum doskonaty. Rozmowa o zaletach $i$ wadach Internetu z prof. R. Tadeusiewiczem, „Tygodnik Powszechny" 23 (2002), s. 5.

5 S. Kowalczyk, Wprowadzenie do filozofii J. Maritaina, Lublin 1992, s. 49. 
nych i roszczeniowych wobec ogółu. Mieć staje się przeszkodą, aby być dla drugiego. Pewne wyrobienie w wychowanku umiejętności dzielenia się sobą z innymi, a także tym, co się posiada, jest istotne dla procesu socjalizacji. Współczesna praktyka wychowawcza pokazuje jednak, że wiele osób zatraciło swoje rozeznanie w kwestii tego, co należy do ich funkcji i na czym polega ich społeczna rola. Wzorce, jakie do niedawna były naśladowane i przekazywane kolejnym pokoleniom $\mathrm{z}$ jednej strony rozprzestrzeniły się, a z drugiej strony uległy całkowitej zmianie. Wielu pedagogów i wychowawców coraz częściej musi się mierzyć ze zjawiskami, które w niepokojący sposób wpływają na kondycję społeczeństwa. Są one w dużej mierze związane z pluralizmem funkcjonującym w wymiarze życia społecznego ${ }^{6}$.

Współczesna technika w zakresie informacji i korzystania z niezliczonej ilości danych ofiaruje człowiekowi również ogromne możliwości realizacji siebie, własnych potrzeb czy odgrywania ról społecznych. Mamy więc mnogość form i stylów życia, co w konsekwencji oznacza często brak uporządkowania i spójności w życiu człowieka, do którego wkrada się niekonsekwencja, epizodyczność i fragmentaryczność. Źródłem satysfakcji życiowej staje się gromadzenie (dóbr materialnych, wrażeń, doświadczeń, certyfikatów itp.), a współwystępująca z nimi prywatyzacja i subiektywizacja poglądów oraz przekonań stwarza korzystny klimat dla przyjmowania wizji świata kreowanego, zwłaszcza przez mass media. Stąd mówi się o dominacji w umysłach ludzi świata wirtualnego nad światem realnym. Ten gwałtowny wzrost znaczenia mediów koresponduje z pomniejszeniem roli dotychczas podstawowych środowisk wychowawczych i socjalizacyjnych, jakimi są np. rodzina czy szkoła. Mamy więc do czynienia z niespotykaną dotąd nieprzejrzystością, niepewnością i płynnością sytuacji społecznych, w których ludzie muszą podejmować różne działania?.

Można zaryzykować twierdzenie, że brak pogłębionej refleksji nad otaczającą rzeczywistością to znamię współczesnej epoki i główna przyczyna zapaści kondycji umysłowej współczesnego człowieka. Sięgając do historii, możemy odnieść się do najstarszej doktryny o trzech zasadniczych

6 Por. Ł. Ryszka, Istota przemian ustrojowo-społecznych dokonujacych sięw Polsce. Perspektywapedagogiczna, w: Pedagogiczne konteksty społecznego wsparcia rodziny, red. G. Godawa, Kraków 2015, s. 11-12.

7 Por. T. Hejnicka-Bezwińska, Pedagogika ogólna, Warszawa 20o8, s. 178. 
dziedzinach racjonalnej aktywności człowieka: teorii - praxis - poiesis. Jako kryterium celowościowe łączą się z nimi odpowiednio prawda - dobro - piękno. A zatem celem poznania teoretycznego jest odkrycie przez człowieka otaczającej go rzeczywistości i jej faktycznej struktury (prawda). Z kolei celem poznania praktycznego jest realizacja rozpoznanego i uznanego dobra. Celem poznania wytwórczego (poietycznego) jest szeroko pojęte piękno ${ }^{8}$.

Kiedy jednak człowiek zapomina i odrywa swój rozum od aksjologicznej triady ludzkiego poznania, rezygnuje z realnej wiedzy o poznawanej rzeczywistości, ale też odrywa się od antropologicznych podstaw aktu poznania. Tym samym zostaje on pozostawiony na pastwę mitów, w których myślenie realne zostaje zastąpione post-myśleniem skłaniającym do uznawania i przyjmowania rzeczywistości taką, jaka jest dla poznawanego podmiotu, a nie ze względu na jej przedmiot ontyczny. Obecna mitomania kreowana za pomocą różnego rodzaju środków masowego przekazu i odbioru, którą reprezentują głównie różne postacie ruchów społecznych, prawie całkowicie zdominowała współczesną przestrzeń publiczną. Media codziennie informują nas o ich działaniach, od ruchów ekologicznych, feministycznych, mniejszości (narodowych, seksualnych), anty- i pro- (aborcyjnych, globalistycznych). W takim globalnym i spluralizowanym społeczeństwie działania tych ruchów bardzo łatwo przeistaczają się w ideologię, która przenika również do świadomości naukowej i edukacyjnej. Ideologia opiera się na micie, który propagowany i nagłaśniany w każdym wymiarze medialnym i społecznym staje się jedynym kierunkiem działania, niemającym jednak nic wspólnego z dociekaniem i poznaniem prawdy.

Można więc wskazać kilka mitów, które są charakterystyczne dla przyjmowania przez współczesnego człowieka narzuconej percepcji rzeczywistości. Mity te mają szczególny wpływ na funkcjonowanie systemów gospodarczo-politycznych, jednak najbardziej narażony na ich działania jest system oświatowo-edukacyjny, który kolejne społeczne pokolenia utrzymuje w nieświadomym przyzwoleniu na szerzące się ideologie.

8 Por. M. Nowak, Teorie i koncepcje wychowania, Warszawa 20o8, s. 40. 


\section{Edukacyjny mit innowacji i postępu}

Istotnym punktem wszelkich przemian społecznych zawsze są elementy systemu oświatowego. Współczesna koncepcja szkoły i to, czego i jak ma nauczać, w dużej mierze zależy od zmian, jakie zachodzą w obrębie życia społecznego, ale również od zmian i perspektyw rozwojowych w świecie. Niezależnie od systemu edukacyjnego pod uwagę zawsze bierze się pewien ideał, którego celem jest ukształtowanie osobowości wielostronnie rozwiniętej, tzn. świadomej istotnych zależności, jakie łączą ją m.in. ze światem przyrody, społeczeństwem czy kulturą, w tym również i nauką. Ten wielostronny rozwój osobowości nie może jednak dokonywać się tylko przez samo poznanie, ale musi łączyć się z jego aktywnym przekształcaniem ${ }^{9}$. Zatem najogólniejszym pedagogicznym założeniem takiego systemu edukacyjnego jest integralny związek i równowaga pomiędzy poznaniem i działaniem ${ }^{10}$.

W konsekwencji cechą przemian i transformacji współczesnych społeczeństw, w tym również polskiego, jest utrata ważności norm i wartości moralnych, zwłaszcza tych, które w sposób naturalny są powiązane, np. $\mathrm{z}$ religią.

Nazywane jest to przejściem od uniwersum symbolicznego dużych grup społecznych do pluralizmu przekonań, światopoglądów, obyczajów, zwyczajów itp. Spowodowało to powstanie nowych wspólnot, które wyznają upowszechniane głównie przez media nowe idee, jak np. idea tolerancji, wielokulturowości, poprawności politycznej itd. ${ }^{11}$

Człowiek, przejmując kontrolę nad wartościami i decydując, które z nich są bardziej właściwe dla niego, kieruje się bardziej usprawiedliwianiem własnych wyborów niż narzuconymi mu wzorami myślenia i działania. W ten sposób szczególnie zakwestionowana zostaje integracyjna funkcja edukacji związanej z upowszechnianiem wartości, norm i wzorów działania moralnego. Ponadto paralelnie ze wzrostem znaczenia mediów

9 Por. F. Bereźnicki, Dydaktyka ksztatcenia ogólnego, Kraków 2001, s. 164-165.

10 Por. Ł. Ryszka, Istota przemian ustrojowo - społecznych dokonujacych sięw Polsce. Perspektywa pedagogiczna, w: Pedagogiczne konteksty społecznego wsparcia rodziny, red. G. Godawa, Kraków 2015, s. 34.

11 Por. T. Hejnicka-Bezwińska, Pedagogika ogólna, Warszawa 20o8, s. 182. 
w kreowaniu świadomości społecznej i uniwersum symbolicznego grup społecznych następuje pomniejszenie roli i znaczenia samej edukacji.

Jan Paweł i upatrywał w tym brak troski o godność człowieka, którego pierwszą przyczyną jest zanik świadomości Boga i kryzys sumienia współczesnego człowieka ${ }^{12}$. Mit współczesnego postępu opiera się na nieustannym poszukiwaniu i niwelowaniu napięcia pomiędzy tym, co stare, bezużyteczne, tradycyjne, zacofane, a tym, co nowoczesne, innowacyjne i modne. Pomysłem na rozwiązanie tego problemu jest stałe zwiększanie bilansu ludzkiego szczęścia poprzez doskonalenie i wprowadzanie nie tylko różnych, nowych systemów organizacji i zarządzania po to, aby osiągnąć panowanie człowieka nad rzeczywistością, ale także budowanie w nim poczucia sprawstwa. Chodzi o to, aby doprowadzić do zmiany społecznego nastawienia, by to, co może być jeszcze funkcjonalne i użyteczne, pozbawić walorów atrakcyjności i pożyteczności, a na jego miejsce wprowadzić nowe, lepsze.

Fakt postępu nauki w zakresie wiedzy doświadczalnej oraz technologii wydaje się oczywisty i niezaprzeczalny. Jednak wywodzenie z niego twierdzenia o równoczesnym postępie nauk społecznych i życia społecznego jest nadużyciem. Przeczą temu choćby doświadczenia xx wieku, kiedy to osiągnięcia nauki szły w parze z regresem moralności, sprowadzając tym samym na świat dramaty w postaci wojen i krwawych rewolucji. Mimo tych doświadczeń mit powszechnego postępu wydaje się wciąż trwać w myśli ludzkiej i w społecznych dyskursach, zwłaszcza na płaszczyźnie edukacyjnej.

Prawo oświatowe w polskiej rzeczywistości również wyraźnie wskazuje, że integralnym elementem działalności szkoły jest jej innowacyjność. Zobligowani ustawowym zapisem są nie tylko kuratoria oświaty, dyrektorzy szkół, ale przede wszystkim sami nauczyciele. Wszystkie osoby odpowiedzialne za procesy edukacyjne w szkole zobowiązane są więc do „poprawy istniejących lub wdrożenia nowych rozwiązań w procesie kształcenia, przy zastosowaniu innowacyjnych działań programowych,

12 Jan Paweł II, Przemówienie na spotkaniu z Prezydentem Republiki Federalnej Niemiec i innymi władzami: Każdy prawdziwy postęp stu̇̇y człowiekowi, (Bonn 15.11.1980), w: Dzieła wszystkie. Nauczanie papieskie Jana Pawła II, red. E. Weron, A. Jaroch, Warszawa 1985, s. 627. 
organizacyjnych lub metodycznych, których celem jest rozwijanie kompetencji uczniów"13.

Szkoła w myśl postępu i poszukiwania innowacyjnych form nauczania staje się więc niejednokrotnie centrum rozrywki i jest nastawiona na organizowanie uczniom atrakcji. Ta „atrakcyjność” szkoły bierze się z przekonania, że aby współczesnego ucznia, który jest niezwykle mocno przywiązany do świata cyfrowego i do wszelkiego rodzaju nowości technologicznych, zainteresować nauką, nauczyciel musi ją przekazać w jak najbardziej nowoczesnej i atrakcyjnej formie. To fałszywe przekonanie, że wiedza musi być jak McDonald - łatwa, szybka, przyjemna i natychmiastowa - powoduje, że nauczyciel już na starcie przegrywa $\mathrm{z}$ atrakcyjną techniką i mediami.

Uczniowie potrzebują wiedzy fachowej i rzetelnej, jednak pęd za tym, co nowe, w znaczeniu również lepsze i przyjemniejsze, jest pokłosiem współczesnej kultury masowej. Szkoła nie powinna być miejscem zdobywania umiejętności koniecznych np. na rynku pracy, ale miejscem pozyskiwania kwantum wiedzy koniecznej do życia we współczesnym świecie oraz formacji obywatelskiej, która pozwoli na krytyczną ocenę przekazu tak medialnego, jak i politycznego oraz ideologicznego.

Szkoła powinna być więc miejscem, w którym dziecko otrzyma:

- wiedzę niezbędną dla życia w społeczeństwie opartym na informacji i niezbędną do aktywnego udziału w życiu społecznym i obywatelskim;

- przygotowanie do działalności praktycznej w oparciu o podstawowe normy moralne i społeczne;

- ukształtowanie przekonania i opartego na nim światopoglądu na świat jako całość;

- ukształtowanie ogólnego rozwoju sprawności umysłowej i poznawczej;

- przysposobienie do wzbudzania motywacji do działania i samoedu$\mathrm{kacji}^{14}$.

Wymienione powyżej zadania szkoły mają kształtować umysłowość wychowanków, rozwijać zmysł wartości i odpowiedniej oceny świata,

13 Zob. Ustawa z dnia 14 grudnia 2016 roku. Prawo oświatowe, art. 55.1.

14 Por. J. Szczepański, Szkoła w społeczeństwie, w: Sztuka nauczania, red. K. Konarzewski, Warszawa 2001, s. $58-59$. 
wprowadzać w dziedzictwo kultury, uczyć zrozumienia drugiego człowieka ${ }^{15}$.

\section{Mit pedagogicznego negatywizmu}

W koncepcji rozwoju moralnego Lawrence’a Kohlberga, opartej na przekonaniu, że rozumowanie logiczne powoduje rozumowanie moralne, co jest warunkiem koniecznym, ale nie wystarczającym, moralność rozwija się w konkretnych stadiach. Jednym z nich jest pojawienie się spostrzegania siebie jako członka grupy, czyli elementu systemu społecznego. Akcent wówczas w osądach moralnych położony jest na prawo, ale również na autorytet i ustalone zasady oraz normy społeczne. W wychowaniu chodzi więc o promowanie dobrego zachowania, które ma polegać na spełnianiu obowiązków i podtrzymywaniu porządku oraz ładu społecznego ${ }^{16}$.

Do istoty celowościowo realizowanego procesu wychowawczego należy również zaspokajanie potrzeb wychowanków. Dla człowieka niezaprzeczalną wartość mają szczególnie potrzeby szacunku, uznania, akceptacji oraz własnej wartości. Potrzeby te odgrywają istotną rolę w powstawaniu autorytetu, a zarazem powstający autorytet łączy się z ich zaspokajaniem. Niezaspokojenie tych potrzeb prowadzi do zaburzeń w zachowaniu, a nawet patologii i samobójstw ${ }^{17}$.

Większość współczesnych teorii wychowawczych skupia się na wysokim poczuciu własnej wartości jako warunku ludzkiego szczęścia. Z kolei cała psychoterapia opiera się na założeniu, że pacjentowi należy pomóc zyskać przekonanie, iż jest wartościowym człowiekiem. Człowiek zaczyna wówczas wierzyć, iż faktycznie tak jest, niezależnie od tego, co sądzą o nim inni. W praktyce jest to niemalże niewykonalne, potrzebujemy bowiem do tego zewnętrznych bodźców, potwierdzających naszą wartość. Tradycyjnie rolę taką spełniał do tej pory autorytet.

Wychowawczy wymiar edukacji związany jest więc z rolą autorytetu lub wzorca osobowego. We współczesnej szkole i kulturze występuje jednak dość często zagrożenie związane z pojawieniem się „fałszywych au-

\footnotetext{
15 Por. Ł. Ryszka, Istota przemian..., dz. cyt., s. 33.

16 Por. J. Mastalski, Zarys teorii wychowania, Kraków 2002, s. 97.

17 Zob. J. Mastalski, Samotność globalnego nastolatka, Kraków 2007, s. 312.
} 
torytetów”, które propagują bardziej konsumpcyjną ideologię życia niż prawdziwe postawy moralne. Jeśli dla młodego człowieka wzorem jest jakiś youtuber czy internetowy streamer, który promuje działanie niezgodne z normami i kulturą, to należy zapytać, dlaczego do tego doszło. Szkoła potrzebuje dzisiaj nauczycieli jako autorytetów. Autorytet jest nam potrzebny również pod względem dydaktycznym, ponieważ dzięki niemu nie musimy wszystkiego sprawdzać i weryfikować. Jest on czymś koniecznym w edukacji, a zarazem nie wyklucza bliskiej relacji czy nawet przyjaźni.

W powszechnym rozumieniu zależności pomiędzy wychowawcą a wychowankiem istotny zawsze był autorytet i pewien rodzaj posłuszeństwa. Jednak to właśnie ten tradycyjny schemat wychowania obarczano winą za poniesione zło m.in. wojen w xx wieku i nazwano autorytaryzmem. W konsekwencji doprowadziło to do zmiany postrzegania całego dotychczasowego systemu wychowawczego. Pojawienie się ruchów kontestacji społecznej, które na różnych poziomach zanegowały istniejący porządek społeczny, spowodowało zredukowanie lub w wielu wypadkach zlikwidowanie władzy wychowawczej, w tym i rodzicielskiej, a skierowanie się w stronę liberalnego pajdocentryzmu. Dziecko stało się centralną postacią wychowania, a raczej wychowawczego nieoddziaływania, czyli negatywizmu wychowawczego. I tak np. w latach 70. xx wieku w Stanach Zjednoczonych powstał ruch zajmujący się prawami dziecka, który postulował, aby „zapewnić każdemu młodemu człowiekowi, nieważne w jakim byłby wieku, wszystkich praw, przywilejów, obowiązków i odpowiedzialności dorosłych obywateli, tak aby mógł z nich korzystać, gdy będzie chciał"18.

W skrajnych orientacjach nowe kierunki wychowania nie tylko wzywały do emancypacji względem dotychczasowych norm i zasad wychowawczych, ale również były przeciwne jakiemukolwiek wychowaniu. $\mathrm{W}$ ten sposób zaczęło kształtować się społeczeństwo, które nie tylko „nie czyni trudności młodemu pokoleniu, lecz wręcz przeciwnie, wynosi młodzież na piedestał"19.

Antyautorytarne i emancypacyjne kierunki postulowały jednocześnie zasadę dialogu w obszarze wychowania i kształcenia, w który należało

18 Por. H. Berner, Wspótczesne kierunki pedagogiczne, w: Pedagogika. Podstawy nauk o wychowaniu, red. B. Śliwerski, t. 1, Gdańsk 2006, s. 235.

19 H. Berner, Współczesne kierunki pedagogiczne, dz. cyt., s. 199. 
włączyć wszystkich jego uczestników. Miało to zapobiegać wzmocnieniu się pozycji silniejszego, czyli w tym wypadku dorosłego jako wychowawcy. Tak więc zarówno nauczyciele, uczniowie, rodzice, jak i wszyscy zainteresowani mieli współdecydować o celach, treściach, metodach nauczania, o strukturach szkoły $i$ innych aspektach związanych z wychowaniem i nauczaniem. Jak pisze Marian Nowak, „przy dokładniejszym wglądzie stawało się jasne, że wnosi to ograniczenia. Jaka jest bowiem zdolność decydowania przez dzieci, które są zależne od nauczycieli (choćby ze względu na wiek), podobnie jak są zależne od rodziców? Okazywało się więc, że nawet w dyskursie wolnym od panowania statecznie zwycięża ten, kto ma więcej czasu, więcej cierpliwości i fizycznej wytrzymałości, podobnie jak to sprawdzało się nawet w dyktaturach" ${ }^{20}$.

Wychowanie antyautorytarne oznacza zachowywanie przez dorosłe osoby w stosunku do dziecka takiego dystansu, który zabezpieczy jego niezależny rozwój i kształtowanie podmiotowości bez zewnętrznych oddziaływań. Oznacza to brak celów wychowawczych, wzorców i wszelkich zamierzonych wpływów. Antyautorytaryzm wyrósł na utopijnej wizji dziecka, które rodzi się dobre i z natury wie, co jest dla niego najkorzystniejsze. Koncepcja wywodząca się z platońskiego natywizmu i powtórzona przez J.J. Rousseau, który mówił że dziecka nie należy stresować, ponieważ ono samo winno określać, czego chce i pragnie się uczyć, a ku wychowaniu moralnemu i religijnemu należy zwrócić się dopiero na samym końcu edukacyjnego działania, stanowi jednak pułapkę ideologiczną zbierającą współcześnie swoje żniwo ${ }^{21}$.

Obecnie antyautorytaryzm przybrał także kształt różnych paragrafów dotyczących praw dziecka. Mit antyautorytarnego wychowania zagościł jednak szczególnie w edukacji w postaci nośnych haseł propagowanych nie tylko przez media informacyjne i społecznościowe, ale także przez nieświadomych wychowawców. Mamy więc hasła: „szkoła podążająca za uczniem”, „szkoła nieskrępowanego rozwoju”, „szkoła dająca wolność bycia sobą”, ,zajęcia umożliwiające pełną ekspresję,, „partnerskie relacje w szkole" itp.

20 M. Nowak, Teorie..., dz. cyt., s. 245.

21 Zob. M. Uliński, Kobieta imężczyzna. Dzieje refleksjifilozoficzno-społecznej, Kraków 2001, s. 119 . 
Człowiekiem musi najpierw pokierować ktoś, aby potem on sam mógł to właściwie robić - zarówno w kontekście siebie samego, jak też w stosunku do drugiego człowieka. W ten sposób kształtują się osobowe relacje $\mathrm{z}$ innymi oparte na wierze, nadziei i miłości ${ }^{22}$.

Jeżeli jednak dominuje w społeczeństwie redukcjonistyczna wizja wolności, która sprowadza wszystko do nieograniczonych i nieskrępowanych normami i zasadami możliwości konstruowania siebie, jest to iluzja i mit. Mit wolności pojętej jako niezależność od czegoś lub kogoś jest niebezpieczny, ponieważ jeśli wychowujemy człowieka w takim przekonaniu, to okazuje się, że jest on potem zupełnie nieprzystosowany do życia, które zmusza do podejmowania pewnych czynności, a przede wszystkim nakłada istotne obowiązki, jak m.in. bycie odpowiedzialnym za swoje czyny. Właściwie pojęta wolność polega nie na ilości wybieranych aktów, ale na tym, żeby wybierać to, co prawdziwe i dobre ${ }^{23}$.

Istnieje więc potrzeba dawania dziecku ograniczeń i nakładania na niego od początku pewnych obowiązków, gdyż paradoksalnie dają one dziecku poczucie bezpieczeństwa. Obowiązki uczą, wychowują, dzieci nabywają dzięki nim cnót, a z czasem odczuwają radość i satysfakcję z dobrze wykonanego i spełnionego zadania. Autorytet jest więc czymś koniecznym w edukacji, a zarazem nie wyklucza wychowania w relacji podmiotowej i nie neguje możliwości znalezienia prawdy. Wyrugowanie autorytetu jest tak naprawdę emanacją ideologizacji edukacji i wychowania, co miało niejednokrotnie miejsce w historii ludzkości. Autorytet wychowawcy nakazuje mu wpływać na kształt edukacji i wybierać to, co sprawia, że dzieci nie tylko go słuchają, ale przede wszystkim otrzymują od niego wartości związane $z$ poznaniem prawdy i dobra.

\section{Mit wychowawczego pragmatyzmu}

Blisko sto trzydzieści lat temu amerykański pedagog John Dewey przeprowadził eksperyment wychowawczy, wcielając w życie nową ideę: nauki przez działanie. Jego pogląd opierał się na twierdzeniu, iż tylko skutecz-

22 Zob. M. Nowak, Podstawy pedagogiki otwartej, Lublin 1999, s. 318.

23 Por K. Wojtyła, Osoba i czyn, Kraków 1985, 201 n. 
ność i praktyczna użyteczność decydują o tym, co jest prawdziwe i dobre. W swojej idei poszedł tak daleko, że uznał myślenie za funkcję pomocniczą ludzkiego działania. Myśl zaabsorbowana działaniem kieruje więc człowieka w stronę odrzucenia wartości autotelicznych. W tej koncepcji wartości mogą być poznawane naukowo i dlatego pytanie, dlaczego coś jest dla jednostki wartością, skierowane jest bardziej ku ich przyczynom, a nie ku racjom odwołującym się do wartości nadrzędnych. Dewey zapoczątkował tym samym nurt edukacyjnego pragmatyzmu, którym zaraził kolejne pokolenia i społeczeństwa.

Przyjmując założenia filozofii pragmatyzmu, oparł on system wychowawczy o zasadę uczenia się przez działanie (learning by doing), które dostosowane do natury dziecka pod względem treści i metod pracy szkolnej miało być związane z aktualnymi uwarunkowaniami i potrzebami społecznymi. Stanowiło to podstawę kształtowania indywidualności dziecka i jego aktywności, a równocześnie służyło jego uspołecznieniu ${ }^{24}$.

Dewey traktuje więc zadania wychowania jako swoisty element życia społecznego, wynikający z podstawowej potrzeby danego społeczeństwa, dotyczący zachowania jego ciągłości życia i rozwoju. Wszystko to opiera na demokracji jako ustroju społeczno-politycznym, w którym wszystko jest podporządkowane i uzależnione od zdolności jednostek do praktycznego i skutecznego działania na jej rzecz ${ }^{25}$.

Pragmatyczna myśl o demokracji kieruje rozważania o wychowaniu także w stronę celów, których osiągnięcie przez jednostkę jest społecznie pożądane i wskazane. Najważniejszym elementem łączącym społeczeństwo z jednostką jest nie rodzina, a dobrze zorganizowana szkoła ${ }^{26}$. Demokracja odgrywa zatem istotną rolę w przyswajaniu sobie treści społecznie pożądanych ze względu na ich przydatność i użyteczność. Takimi właśnie demokratycznymi pojęciami są wiedza pragmatyczna i pragmatyczne wychowanie. W ten sposób do szkoły i edukacji wkrada się przekonanie, że tylko wiedza użyteczna staje się atrakcyjna i celowa ze względu na jej przydatność, np. na rynku pracy. Z kolei w pragmatycznym wychowaniu chodzi o hołdowanie zasadzie wychowania do tolerancji i wolności jako stałych aksjomatów społecznego postępowania.

24 Por. J. Dewey, Wybór pism pedagogicznych, opr. J. Pieter, Wrocław 1967, s. 14.

25 Por. J. Dewey, Wybór pism pedagogicznych..., dz. cyt., s. 36-37.

26 Por. J. Dewey, Wybór pism pedagogicznych..., dz. cyt., s. 15. 
Źródłem tego zjawiska jest również wspomniany nurt antyaretologiczny, w myśl którego sprowadzamy często człowieka do instynktów, zmysłów i nawyków, przez co staje się on bytem bezrefleksyjnym. Degradujemy przez to również jego zamysł i refleksję nad istotą poznawanej rzeczywistości i faktów, czyli pozbawiamy umiejętności, którą starożytni Grecy nazywali kontemplacją. Konsekwencją więc odrzucenia kontemplacji jest wszechobecny praktycyzm w edukacji, który często pozbawia człowieka głębszego rozumienia świata, a następnie umożliwia manipulowanie człowiekiem.

W społeczeństwie poddanym demokratycznym regułom należy umożliwić wychowankowi przyswojenie sobie najważniejszych elementów, którymi dana wspólnota żyje, po to, aby jednostka mogła odkryć w sobie najlepsze cechy społecznie przydatne, nie tyle mające swoją podstawę w prawdzie, dobru i pięknie, ile w większościowym społecznym udziale danej ideologii. Stąd jest już bardzo blisko do kolejnego pożądanego w demokratycznym społeczeństwie hasła, tj. tolerancji. Jeśli w społeczeństwie uznanym za demokratyczne istnieje wielość i pluralizm wszelkich form życia, musi występować relatywizacja pojęć i wartości. Jeżeli więc współczesna demokracja kieruje się relatywizmem - a o tym, co jest zgodne z prawdą, nie decyduje obiektywizm, ale forma umowy społecznej, na którą ogromny wpływ wywiera np. aktualna polityka, sterująca jednocześnie edukacją, to taka demokracja - jak stwierdza Jan Paweł II - „, latwo się przemienia w jawny lub zakamuflowany totalitaryzm" ${ }^{27}$.

Paradoksalnym przejawem kształtowania świata dziecka przez wychowawczy pragmatyzm jest np. edukacja seksualna, której jednym $\mathrm{z}$ istotnych elementów jest - jak się okazuje - idea równego traktowania związków hetero- i homoseksualnych. Chodzi więc o to, aby w nauczaniu i wychowaniu uznać wszystkie społeczne i kulturowe wzorce zachowań za równoprawne, a im więcej ich dziecko pozna, tym będzie lepiej wyedukowane i przystosowane do nieustannie zmieniających się warunków $\mathrm{w}$ demokratycznym i pluralistycznym społeczeństwie.

Przemiany, jakie następują w społeczeństwie polskim, wyraźnie widać na przykładzie zmian, jakie zachodzą w zakresie moralności. Demokra-

27 Jan Paweł II, Wolność religijna podstawa praw ludzkich. Orędzie do Sekretarza Generalnego ONZ, 2 grudnia 1978, w: Jan Pawet II, Nauczanie spoteczne 1978-1979, t. II, Warszawa 1982, s. 205. 
tyzacja społeczeństwa oraz związana $\mathrm{z}$ nią pragmatyczna edukacja sprawiają, iż trudno jest obecnie mówić o względnie jednolitym porządku normatywnym, który w jakiś sposób scalałby zarówno społeczne, jak i indywidualne formy życia moralnego, zwłaszcza w obrębie edukacji, której istotnym przecież zadaniem powinno być nie przekazanie wiedzy, ale nauczenie myślenia w oparciu o podstawy antropologiczne i aksjologiczne.

\section{Zakończenie}

Zagadnienie edukacji jawi się dziś jako szczególnie ważne w każdej społeczności ludzkiej, szczególnie zaś wtedy, gdy ta podlega przeobrażeniom i zmianom. Również w polskiej rzeczywistości - w wyniku trwającego etapu przemian - współczesne społeczeństwo dotyka kryzys wartości i autorytetów, w dużej mierze spowodowany konstruowaniem rzeczywistości w oparciu o ideologie i utopie, oddalone od obiektywnej prawdy. Wielu pedagogów i wychowawców musi więc w swojej pracy wychowawczej coraz częściej mierzyć się ze zjawiskami, które w niepokojący sposób wpływają na kondycję społeczeństwa, co z kolei rodzi pytanie o przyszłość młodego pokolenia. Realizm nakazuje patrzenie na rzeczywistość przez pryzmat sensu rzeczy i spraw. Szkoła jako instytucja dobra społecznego, u której podstaw leży wielowiekowa tradycja, powinna kierować cele wychowawcze przede wszystkim w stronę rozwoju moralnego młodego pokolenia, a cele kształcenia kierować ku nauce rozumowania i myślenia. Sensem powodzenia tej misji edukacji jest jej usamodzielnienie, tzn. nie należy dopasowywać szkoły do pragnień i życzeń ucznia ani do wizji tzw. resortowych władz, ani też do wygody nauczycieli. Naczelnym zadaniem szkoły i prowadzonej w niej edukacji powinno stać się przywrócenie triadzie ludzkiej aktywności realności swojego znaczenia. Prawdzie, zredukowanej do ideologii i poglądów człowieka, należy przywrócić pierwotny sens, jakim jest uzgodnienie poznania z rzeczywistością. Z kolei wartości dobra należałoby odebrać status degradującej go użyteczności, a piękno uwolnić z mitu nowomody i postępu.

Pedagogiczna postawa zdrowego realizmu człowieka powinna być dzisiaj szczególnie ceniona i pożądana w społeczeństwie, aby zminimalizować skłonność do idealizowania życia czy swego rodzaju utopijności 
w myśleniu. Jej brak prowadzi do nieumiejętności rozpoznawania realiów sytuacji oraz własnych możliwości. Dlatego szczególna rola w kształtowaniu właściwych postaw i dawaniu przykładu powinna przypadać wychowawcom, którzy mają wprowadzać dzieci w realistyczne rozumienie świata ${ }^{28}$.

\section{Abstrakt}

\section{Pedagogiczne interpretacje mitów współczesnej edukacji człowieka}

Współczesna technika w zakresie informacji i korzystania z niezliczonej ilości danych ofiaruje człowiekowi ogromne możliwości realizacji siebie, własnych potrzeb czy odgrywania ról społecznych. Mnogość form i stylów życia w konsekwencji oznacza często brak uporządkowania i spójności w funkcjonowaniu człowieka. Do jego życia wkrada się niekonsekwencja, epizodyczność i fragmentaryczność. Służy to szerzeniu się różnego rodzaju ideologii, mitów i utopii. Obecna mitomania kreowana za pomocą różnego rodzaju środków masowego przekazu i odbioru, którą reprezentują głównie różne postacie ruchów społecznych, prawie całkowicie zdominowała współczesną przestrzeń publiczną. Ideologia przenika również do świadomości naukowej i edukacyjnej. Można wskazać kilka mitów, które są charakterystyczne dla przyjmowania przez współczesnego człowieka narzuconej percepcji rzeczywistości. Mity te mają szczególny wpływ na funkcjonowanie systemów gospodarczo-politycznych, jednak najbardziej narażony na ich działania jest system oświatowo-edukacyjny, który kolejne społeczne pokolenia utrzymuje w nieświadomym przyzwoleniu na szerzące się ideologie.

Słowa kluczowe: szkoła, edukacja, kształcenie, wychowanie, społeczeństwo

28 Por. M. Nowak, Teorie..., dz. cyt., s. 372-373. 


\section{Abstract}

Pedagogical interpretations of modern education myths

The possibilities people get from modern technology in the areas of information and data make huge opportunities in realization of self, own needs or participating in social roles. And so we have multiple forms and styles of life, which in consequence often means lack of order and consistency in human's life. There are risks of inconsistency, episodicality and fragmentation. All this becomes potent ground for different kinds of ideologies, myths and utopias. Present myth-thinking which is created with help of mass-media and social movement gurus, almost entirely dominated today's social space. Ideology also finds its way to science and education. We can point out few myths, which impacted the most of in today's perception of reality. These myths have significant influence on the geo-political systems. Having said that, the most endangered is educational system which keeps allowing to spread these ideologies.

Keywords: school, education, upbringing at school, society

\section{Bibliografia}

Bereźnicki F., Dydaktyka ksztatcenia ogólnego, Kraków 2001.

Berner H., Wspótczesne kierunkipedagogiczne, w: Pedagogika. Podstawy nauk o wychowaniu, red. B. Śliwerski, t. 1, Gdańsk 2006, s. 195-275.

Dewey J., Wybór pism pedagogicznych, opr. J. Pieter, Wrocław 1967.

Hejnicka-Bezwińska T., Pedagogika ogólna, Warszawa 2008.

Jabłońska M.R., Człowiek w cyberprzestrzeni. Wprowadzenie do psychologii internetu, Łódź 2018.

Jan Paweł II, Przemówienie na spotkaniu z Prezydentem Republiki Federalnej

Niemiec i innymi władzami. Kazdy prawdziwy postęp stuży człowiekowi, (Bonn 15.11.1980), w: Dzieła wszystkie. Nauczanie papieskie Jana Pawła II, red. E. Weron, A. Jaroch, Warszawa 1985, s. 626-630. 
Jan Paweł II, Wolność religijna podstawa praw ludzkich. Orędzie do Sekretarza Generalnego ONZ, 2 grudnia 1978, w: Jan Pawet II, Nauczanie społeczne 1978-1979, t. II, Warszawa 1982.

Kowalczyk S., Wprowadzenie do filozofii J. Maritaina, Lublin 1992.

Legutko P., Szum doskonaty. Rozmowa o zaletach i wadach Internetu z prof. R. Tadeusiewiczem, „Tygodnik Powszechny” 23 (2002).

Mastalski J., Samotność globalnego nastolatka, Kraków 2007.

Mastalski J., Zarys teorii wychowania, Kraków 2002.

Nowak M., Podstawy pedagogiki otwartej, Lublin 1999.

Nowak M., Teorie i koncepcje wychowania, Warszawa 2008.

Ryszka , Istota przemian ustrojowo-społecznych dokonujących się $w$ Polsce. Perspektywa pedagogiczna, w: Pedagogiczne konteksty społecznego wsparcia rodziny, red. G. Godawa, Kraków 2015, s. 8-39.

Szczepański J., Szkoła w społeczeństwie, w: Sztuka nauczania, red. K. Konarzewski, Warszawa 2001.

Tyszka Z., Rodzina wświecie wspótczesnym - jej znaczenie dla jednostki i spoteczeństwa, w: Pedagogika społeczna. Człowiekwzmieniajacym sięświecie, red. T. Pilch, I. Lepalczyk, Warszawa 1995.

Uliński M., Kobieta i mężczyzna. Dzieje refleksji filozoficzno-społecznej, Kraków 2001.

Ustawa z dnia 14 grudnia 2016 r. Prawo oświatowe, art. 55.1.

von Weizseacker E.U., Wijkman A., Kapitalizm, krótkowzroczność, populacja i zniszczenie planety. Raport Klubu Rzymskiego, Sztokholm 2018.

Wojtyła K., Osoba i czyn, Kraków 1985. 